商分子䀫文集 (Kobunshi Ronbunshu), Vol. 43, No. 7, pp. 395-398 (July, 1986)

\title{
ポリエステルレジンコンクリートの水中における耐久性
}

\author{
小林 尚吾*1 $・$ 佐藤 博*1
}

(受付 1985 年 10 月 18 日・变査終了 1986 年 2 月 5 日)

\begin{abstract}
更 旨シェステルレジンコンクリートの水中での耐久性を明らかにするため, 草津沮泉(平均

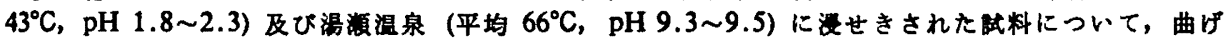

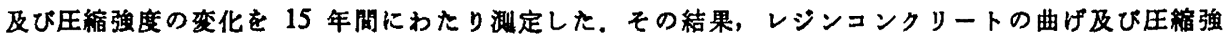

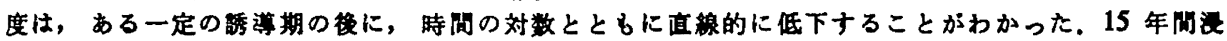

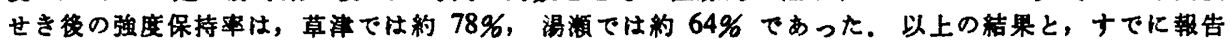
されている水中での促進試結果をととに, ボリエステルレジンコンクリートの劣化を推定する実駼 式を算いた。
\end{abstract}

\section{1 茷}

砂や砂利などの骨材と合成樹脂の結合材から成るレシ ンュンクリートは，整量で高蝃度であるばかりでなく， 酎萝品性や耐凍結骶解性に優れているなどの特長をるつ 材料として，各方面に応用が広がっている. 現在, レシ ンコンクリートK用いられている合成樹脂は，主として 程济的理由から活とんどが不忽和ポリエステル樹脂であ る. この楜脂は内部にエステル基を有するため，加水分 解による劣化を生じる扎それがあるので，この材料を本 格的な棬造材料に応用するためには，この材料の水に対 する稆久性の把握が必要である。

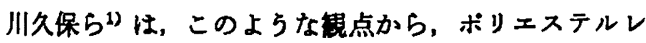
シンュンクリートの村水性，耐薬品性について研究を行 った，彼らは，温度と水素イオン䈨度 $(\mathrm{pH})$ を变えた水 中促進劣化試踰を行い，pH の差異よりも温度の差異の 方が影著に劣化に影雪することを明らかにするととる に，水炈るボェステルレシシンンクリートの劣化を 推定するための実鈳式を求めた.

著者らは，川久保らのこの仕事を引継き，同じ組成の ポリステルレシシンコンクリートについて，办の存在す る実際の㻴境下での劣化举動を約 15 年にわたり追跡し た. 桭境として，繁办や酸、アルカリの存在という点で 取す薪酷な温泉を採り上げた。本報告は，この検討の結 果についてまとめたものである.

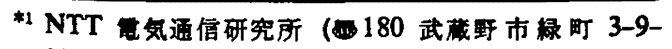
11)

\section{2 实駼方法}

\section{1 供試体の作製}

試嗆に用いたレジンュンクリートの材料の性質及び西 合比を Table 1 に示す.これら材料をミキサーにより 十分練り混ぜたのち，寸法 $6 \times 6 \times 24 \mathrm{~cm}$ の角柱状に成 形し, ゲル化後, $100^{\circ} \mathrm{C}, 3 \mathrm{~h}$ のアフタキュフを行った。 砂及び砂利は事前に十分乾嬠して用いた。 また，骨材に ついてはンランカップリング剂処理を行った．触媒及び 促進剂として，それぞれメチルエチルケトンベルオキシ ド及びナフテン酸コハルトを用いた。

\section{2 供代体の浸せき}

実験地として, 強酸性温泉（群馬県草津温泉）とアル

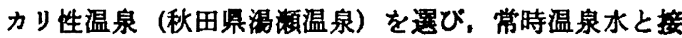
蜰する場所に供試体を漫せきした．草津温泉では，温泉 水が地中を流れる剒所（西の河原）下穴を堸り，供試体 を曼手方向に約 $1 \mathrm{~cm}$ 間隔に立てて浸せきした．浸せき 地の水温及び $\mathrm{pH}$ は，浸せき期間中に Table 2 に示す よらに変動した. 草津温泉ではこのはか, 温度 $66^{\circ} \mathrm{C}$, pH 1.1 1.3 の淐烟にも数個の供試体を浸せきし，比較

Table 1. Mix proportions for resin concrete

\begin{tabular}{lc}
\hline \multicolumn{1}{c}{ Material } & $\begin{array}{c}\text { Mix proportion } \\
(\text { wt } \%)\end{array}$ \\
\hline Orthophthalate-type & 10.5 \\
unsaturated polyester & \\
Ground calcium carbonate & 12.0 \\
Sand $(<5 \mathrm{~mm})$ & 45.0 \\
Gravel $(5 \sim 20 \mathrm{~mm})$ & 32.5 \\
\hline
\end{tabular}


Table 2. Chemical composition, temperature, and $\mathrm{pH}$ of the hot springs where the resin concrete was immersed

\begin{tabular}{|c|c|c|c|c|c|c|c|c|c|}
\hline \multirow{2}{*}{ Hot spring } & \multicolumn{6}{|c|}{ Chemical composition (mg/l) } & \multirow{2}{*}{ Total } & \multirow{2}{*}{$\underset{\left({ }^{\circ} \mathrm{C}\right)}{\text { Temp. }}$} & \multirow{2}{*}{$\begin{array}{l}\mathrm{pH} \\
\left(15^{\circ} \mathrm{C}\right)\end{array}$} \\
\hline & $\mathbf{K}^{+}$ & $\mathrm{Na}^{+}$ & $\mathrm{Ca}^{++}$ & $\mathbf{M g}^{++}$ & $\mathrm{Fe}^{++}$ & $\mathbf{A l}^{+++}$ & & & \\
\hline Kusatsu & 11.3 & 30.6 & 126.8 & 50.2 & 17.3 & 110.4 & 346.6 & $48 \sim 38$ & $1.8 \sim 2.3$ \\
\hline Yuze & 12.7 & 117.6 & 27.5 & 0.8 & 0.5 & 9.9 & 169.0 & 63 & $9.3 \sim 9.5$ \\
\hline
\end{tabular}

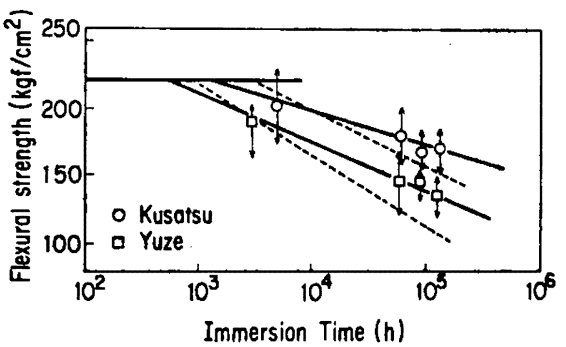

Fig. 1. Change in fiexural strength with immersion time in hot spring.

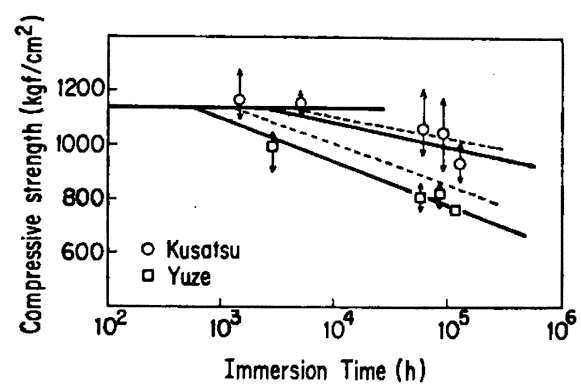

Fig. 2. Change in compressive strength with immersion time in hot spring.

試料とした．淂瀬温泉では，温泉の渴だめの中に井げた 状に稓み重ねて浸せきした，湯瀬温泉での水温及び $\mathrm{pH}$ の变䖝は比整的小さかった．温泉水の化学組成，温度な らびに pH を Table 2 にまとめて示す.

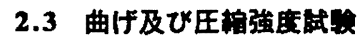

供試体について，JISA 1184 「ホシェステルレジンュ ンクリートの曲げ試拿方法」及び JISA 1183 「はりの折 片によるポリエステルレシシンンンリートの圧縮強度試 験方法」Kよって, 曲げ及び王縮強度試検を行った.

\section{3 結果と考寀}

温泉水に浸せきされたボリエステルレジンュンクリー トの曲げ 及び压縮強度の経時変化を，それぞれ Fig. 1 及び Fig. 2 に示す. 曲げ及び圧縮強度は，ある一定の 誘導期の後に浸せき時間の対数とともに直線的に減少す る.このことは，強度の低下は誘㝵期直後に比較的大き
く，その後時間とともに強度低下が縟僈になっていくこ とを意味している. また，誘尊期の存在は，レシシンコン クリートの内部への水の浸透と浸通した水による樹脂の 加水分解という 2 段階の劣化機構を考えることの妥当性 を示していると考えられる。

温泉水浸せきによる強度低下は，草津西の河原では 15 年間に約 $22 \%$ ，湯瀬では 15 年間に約 36\% であっ た. また，草津晹畑では7 カ月漫せき後の強度低下は約 $10 \% ， 7$ 年間浸せきでは約 35\% であった，浸せき地の 苛酷な㻴境と 15 年とい5長期の時間的経過を考虑すれ ば、この材料はかなり優秀な材料であるといえる。特 に，セメントコンクリートが 3 4 年で崩壤してしまら 强酸性温泉地では, その構造材料としての有利性は明白 である.

ボレエステルレジンコンクリートの水中に斿ける耐久 性については，すでにいくつかの報告がある22 。温泉

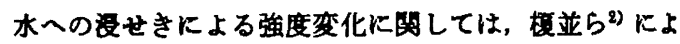
るものがある. 彼らは, オルトフタル酸系不铇和ボリェ ステルを結合材とするレシンンンクリートを、温度 $66^{\circ} \mathrm{C}, \mathrm{pH} 1.1$ の強酸性温泉に没せきすると，1力月て 約 $80 \%$ の强度低下を起こすことを報告しているっこの 結果は，上述の草津湦畑での結果と大きなくい進いがあ

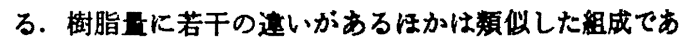
るにるかかわらず，両者にこれ汪ど大きな䢖いがある理 由は明確ではないが，骨材の種類や処理方法あるいは混 合方法の䢖いのためではないかと考えられる.

川久保らはは、ホリエステルレシシンコンクリートの本 の存在下における劣化について, 内部への水の浸道とそ の水による樹脂の加水分解とい5 2 段階の劣化機榜を考 え, 次式を算いた。

$$
P=P_{0}-f(T) \log \frac{t}{\tau} \quad(t \geqq \tau)
$$

ここに, $P$ は曲げまたは压縮強度, $P_{0}$ は初期強度 $(t=\tau$ の時の $P$ の值), $f(T)$ は強度変化実跧式の㑯斜， $t$ 时時 間, ては誘眷期である. 中性の水中Kおける劣化につい て得た川久保らの実験式を今回の浸せき実検の温度飞道 用した結果を Fig. 1 と Fig. 2 亿点線で示寸.

上述の推定値と実測値の間にはかなりのくい荤いがみ られる.このくい䢖いの原因として，温泉水中の酸、丁 ルカリの劣化促進効果が考えられる.この考え方は压樎 


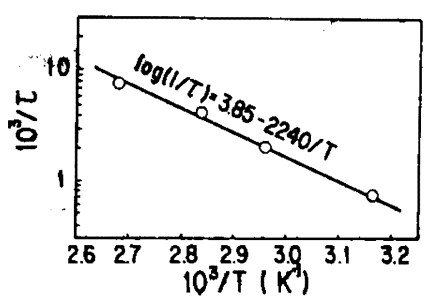

Fig. 3. Relation between $1 / \tau$ and $1 / T$ for change in flexural strength.

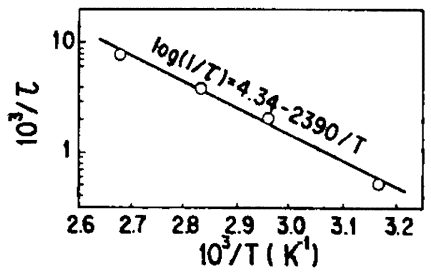

Fig. 4. Relation between $1 / \tau$ and $1 / T$ for change in compressive strength.

強度の挙動を説明できるが, 実測値の直線と推定値の直 線が交っている曲げ強度の挙動を説明することはできな い，すなわち，酸またはフルカリが初期には劣化を促進 するが，あるところから逆に劣化を㧕制するといらこと は考えにくい. 川久保らによれば,ポリエステルレジン コンクリートの劣化K与える影零は， $\mathrm{pH}$ よりも温度の

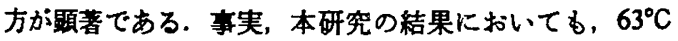
のフルカリ温泉である晹瀬に和ける浸せき7年後の強度

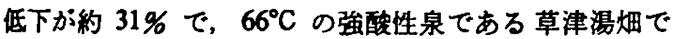
の浸せき7年後の強度低下（約 35\%）とほとんど同じ であった. 更に，㮩並ら 2) 忙，同じ盜度の醊性静水，酸 性流水及び浄水中でのインフタル酸系ボリエステルレシ ンコンクリートの劣化の程度に大きな差はないと報告し ているので, オルトフタル酸采のすのについてむ同様と 考えてよいと思われる.そこで，ここでは，上述のくい 䢖いは劣化推定式が比較的短期の促進試験から求められ たための證差であるとの見方に立ち，温度の要因にのみ 着目して（すなわち，酸やアルカリの要因を無視して）， ボリエステルレジンュンクリートの劣化推定のための释 领式の隹正を試みる. 経输式を求めるにあたって, 本研 究の浸せき試験結果のほか，川久保らの 80 及び $100^{\circ} \mathrm{C}$ での促進試稀結果を利用した。

䅎学期ての温度依存性を Fig. 3 と 4 亿示す。曲げ 強度についての実倹式は次式で与えられる。

$$
\log \frac{1}{\tau}=3.85-\frac{2240}{T}
$$

ここで，Tは絶対温度である. 压維強度については次式 のとおりである.

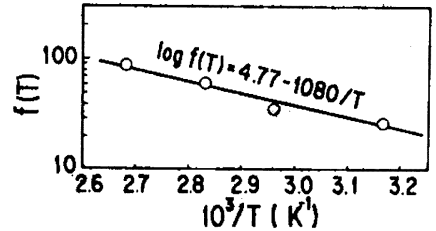

Fig. 5. Relation between $f(T)$ and $1 / T$ for change in flexural strength.

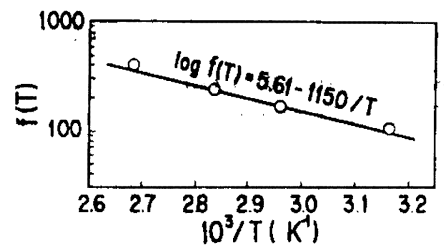

Fig. 6. Relation between $f(T)$ and $1 / T$ for change in compressive strength.

$$
\log \frac{1}{\tau}=4.34-\frac{2390}{T}
$$

強度变化実験式の攧斜 $f(T)$ の温度依存性を Fig. 5 と Fig. 6 に示す. 曲げ強度についての $f(T)$ と $T$ と の咸係讷次式で与えられる。

$$
\log f(T)=4.77-\frac{1080}{T}
$$

王縮強度に対しては，次式が得られる。

$$
\log f(T)=5.61-\frac{1150}{T}
$$

以上の経験式は, 酸やアルカリの要因を無視して求め たが，これらの要因が温度の奻果より小さいとはいえ， 劣化を促進している可能性は十分ある. したがって，酸 やアルカリの影歓がなかったすのとして求めた上述の経 釦式から得られる推定値は，中性の環境では安全側の值 を与えると考えられる。

上述の経検式を用いて， $15^{\circ} \mathrm{C}$ の通常の地下水中に拉 けるポリエステルレジンコンクリートの 50 年後の強度 低下を推定すると，曲げ強度で約 $8.2 \%$ ，压縮強度で約 6.4\% であり，この材料は通常の地中できわめて安定で あることがかかった。

\section{4 結}

不飽和ポリェステルと骨材から成るレジンコンクリー トを 15 年にわたり温泉中に浸せきし，曲げ及び压縮强 度の变化を追跡した. 15 年間の浸せき後の強度保持率 は，平均 $43^{\circ} \mathrm{C}$ の強酸性温泉で約 $78 \%, 63^{\circ} \mathrm{C}$ のアルカ リ性温泉では約 64\% であった.この結果と，すで報 告されている室内促進劣化試験の結果をるとに，ボリエ ステルレジンコンクリートの強度劣化推定のための経験 式を導いた。この結果は，構造材料としてのポリエステ 
ルレジンコンクリートの粠造設計のための基整データと

して活用できると考える.

\section{文辣}

1）川久保専吉, 山本 榑, 村井信夫, 笹息洋一, 材料, 24, 380 (1975).

2）标並 昭, 国府田 诚，田村一好，陉浦光男，

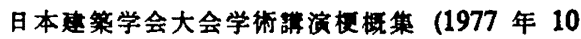

月), p. 293.

3) Y. Ohama, Proc. Jpn. Congr. Mater. Res., 20, 176 (1977).

4）阅 博，大即信明，港唀技研资料，No. 275 (1977).

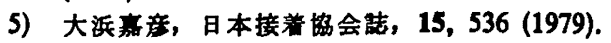

6) T. Sugama, L. E. Kukacka, and W. Horn, Cem. Concr. Res., 11, 429 (1981).

Long-Term Stability of Polyester Resin Concrete under Water

Shogo Kobayashi*1 and Hiroshi SATo*1

${ }^{* 1}$ NTT Electrical Communications Laboratories (9-11, Midori-cho 3-chome, Musashino, Tokyo, 180 Japan)

In order to investigate the long-term stability of polyester resin concrete under water, the resin concrete was immersed in Kusatsu hot spring $\left(43^{\circ} \mathrm{C}, \mathrm{pH} 1.8 \sim 2.3\right)$ and Yuze hot spring $\left(66^{\circ} \mathrm{C}, \mathrm{pH} \mathrm{9.3} \mathrm{9.5)} \mathrm{for} 15\right.$ years, and the flexural and compressive strength were measured as a function of immersion time. It was shown that after an induction period an approximately linear relationship exists between the flexural or compressive strength and the logarithm of the time. The retention in mechanical strength of the resin concrete immersed in Kusatsu hot spring for 15 years was about $78 \%$, and that in Yuze was about 64\%. Using these results and the results which had been obtained from accelerated experiments in water, an experimental equation for durability of polyester resin concrete in water was derived.

KEY WORDS Long-Term Stability under Water / Polyester Resin Concerete / Flexural Strength / Compressive Strength / Hot Spring /

(Received October 18, 1985: Accepted February 5, 1986)

[Kobunshi Ronbunshu, 43 (7), 395-398 (1986)] 